\title{
TP53 Negative
}

National Cancer Institute

\section{Source}

National Cancer Institute. TP53 Negative. NCI Thesaurus. Code C156049.

An indication that TP53 expression or activity has not been detected in a sample. 